


\section{Hellenistic Culture and Society}

General Editors: Anthony W. Bulloch, Erich S. Gruen, A. A. Long, and Andrew Stewart

I. Alexander to Actium: The Historical Evolution of the Hellenistic Age, by Peter Green

II. Hellenism in the East: The Interaction of Greek and Non-Greek Civilizations from Syria to Central Asia after Alexander, edited by Amélie Kuhrt and Susan Sherwin-White

III. The Question of "Eclecticism": Studies in Later Greek Philosophy, edited by J.M. Dillon and A. A. Long

IV. Antigonos the One-Eyed and the Creation of the Hellenistic State, by Richard A. Billows

V. A History of Macedonia, by R. Malcolm Errington, translated by Catherine Errington

VI. Attic Letter-Cutters of 229 to 86 B.C., by Stephen V. Tracy

VII. The Vanished Library: A Wonder of the Ancient World, by Luciano Canfora

VIII. Hellenistic Philosophy of Mind, by Julia Annas

IX. Hellenistic History and Culture, by Peter Green et al.

X. The Best of the Argonauts: The Redefinition of the Epic Hero in Book One of Apollonius' Argonautica, by James J. Clauss

XI. Faces of Power: Alexander's Image and Hellenistic Politics, by Andrew Stewart

XII. Images and Ideologies: Self-definition in the Hellenistic World, by A.W. Bulloch et al.

XIII. From Samarkhand to Sardis: A New Approach to the Seleucid Empire, by Susan Sherwin-White and Amélie Kuhrt

XIV. Regionalism and Change in the Economy of Independent Delos, by Gary Reger

XV. Hegemony to Empire: The Development of the Roman Imperium in the East from 148 to 62 B.C., by Robert Kallet-Marx

XVI. Moral Vision in the Histories of Polybius, by Arthur M. Eckstein

XVII. The Hellenistic Settlements in Europe, The Islands, and Asia Minor, by Getzel M. Cohen 


\section{Hellenistic Philosophy \\ of Mind}





\title{
Hellenistic Philosophy of Mind
}

\author{
Julia Annas
}




\author{
University of California Press \\ Berkeley and Los Angeles, California \\ University of California Press, Ltd. \\ London, England \\ (C) 1992 by
}

The Regents of the University of California

First Paperback Printing 1994

Library of Congress Cataloging-in-Publication Data Annas, Julia.

Hellenistic philosophy of mind / Julia Annas.

p. cm. - (Hellenistic culture and society)

Includes bibliographical references and index. ISBN 0-520-07659-1 (pbk.)

1. Philosophy of mind-History. 2. Philosophy, Ancient.

3. Stoics. 4. Epicurus. I. Title. II. Series.

B187.M55A56 1991

$128^{\prime} .2^{\prime} 0938-\mathrm{dc} 20$

91-10694

CIP

Printed in the United States of America

9876543321

The paper used in this publication meets the minimum requirements of American National Standard for Information Sciences-Permanence of Paper for Printed Library Materials, ANSI Z39.48-1984. @ 